\title{
A Structural Analysis of the Writing Errors Committed by Foundation Students at Arab Open University, Oman
}

\author{
Elnaz Valaei Bakhshayesh ${ }^{a}$
}

\begin{abstract}
English is considered as Arab students' second language which is not used frequently in their daily conversations. Since writing in English is a challenging experience for Omani students, errors in grammar and sentence structures were identified in bridging language courses (foundation level 2) in the field of ESL (English as a Second Language). Learners' errors were considered positively as the best sources to identify students' limitations in English writing. The present study investigates the structure errors of Omani students' writings in English in foundation level 2 at Arab Open University. The focal aim is to study the errors that Omani students commit when they are using adjectives + nouns, indefinite articles, and subordinate conjunction "because". Results show that Omani students committed the following common errors: misplacement of adjectives, omission of the indefinite articles, and wrong structure of the subordinate conjunction (because). The prime aim of this study is to examine the students' aforementioned structural errors which are the result of the interference of their mother-tongue. In order to achieve these aims, students were asked to write two different topics. Finally, this research suggests further recommendations for further studies which might ameliorate students' learning by adopting appropriate strategies for teaching.
\end{abstract}

\section{Keywords}

Writing errors analysis, foundation English, Omani students

Writing is one of the most important skills which appears to be extremely challenging and different experience compared with other language acquisition skills for Arab native speakers. As Abdulkareem (2013) stated in his research on Arab learners' problems in academic writing "Most students commit many mistakes related to sentence structure" (Abdulkareem 2013: 1553). In this study, evidently, the most frequent errors that Arab students committed were mainly the misplacement of the adjective and noun, omission of indefinite article, and wrong structure of subordinate conjunction - "because". The reason behind choosing writing skill is to observe and study how students express themselves and communicate which can be recorded as the best source of samples for studying. The major focus of this study is on the errors committed by ESL (English as a Second Language) learners in using adjectives + nouns, the use of indefinite article and subordinate conjunction "because". This study aims to discuss the

\footnotetext{
aArab Open University, Oman

Correspondent Author:

Elnaz Valaei Bakhshayesh, 130 Azaiba, (Muscat), Sultanate of Oman, PO box: 1596

E-mail: elnazvalaei79@gmail.com
} 
committed errors appearing in the paragraph writings which are evidently due to the interference of the mother-tongue. For this purpose, students' writings are used as a data to furthermore examine such phenomena.

\section{SIGNIFICANCE OF STUDY}

This study can help L2 instructors in stressing more emphasis on their students' errors, caused by L1 inteference, which are the sources of the errors of the aforementioned structures. After reviewing the relevant literature, it has been noticed that there was no research conducted on error analysis at Arab Open University in Oman. This is the first study ever carried out at the English Department at Arab Open University. Knowing the fact that there have been numerous studies on Arab learners' errors, this study only focuses on the structural errors committed by Omani students at Arab Open University. There is only one study conducted on Omani students, at Sohar University, mainly focusing on the question formation in the English writing. Since writing (paragraphs, essays, reports, letters, etc.) in English is closely attached to the students' professional and academic life, this study was conducted to raise students' awareness of the committed errors as well as developing their accuracy in L2 writing.

\section{OBJECTIVE OF STUDY}

One of the objectives of this study is to identify and discuss Arab learners' most frequent errors committed in their writings. The second objective is to discuss how the first language structures influence learner's second language acquisition.

\section{LIMITATIONS OF STUDY}

This study is limited in that it only used one section of English Foundation Level at Arab Open University in
Oman, in further perspectives, a new study is required to apply the same methodology to observe the performance of other students in larger number in different groups.

\section{REVIEW OF LITERATURE}

Regarding the importance of errors in developing the second language, many studies have been conducted in order to investigate, identify, and analyze students' errors. These studies discuss the types and causes of the errors students commit in L2 acquiring. Paying attention to errors in L2 acquisition is significant when both the performance and the output of the students' learning are involved.

In this respect, Arab students' learning strategies have inspired both teachers and researchers to study and examine Arab students' second language acquisition. The main focus of these studies was to study the cases and types of the most common errors Arab learners were committing. Regarding Arab students' common errors, researchers have reached significant conclusions, some of the examined errors were attributed to the influence of L1 while others stated that students' errors are due to the difficulty of L2, which is not the focus of this study.

One of the studies conducted in Oman, at Sohar University, revealed the reasons that cause difficulties in forming correct English question. The results of Al-Mekhlafi's (2013) study listed the difficulties that Omani student and teachers face as: auxiliary omission, auxiliary replacement, auxiliary subject agreement, verbal form concord, auxiliary subject inversion, auxiliary redundant, wrong question word and verb inverted. According to the achieved results, he concluded that the difference between L1 and L2 is the cause of errors in question formation.

$\mathrm{Na}$ 'ama (2011) studied a random sample of three levels at the English Department, Faculty of Education of Yemeni students, focusing on data collection. He gave a critical analysis of errors made 
by Yemeni students in the area of English consonant clusters system which sounded difficult for these students. He investigated the students' errors in the English cluster. The results of this study revealed three sources of students' difficulties in pronouncing English consonant clusters properly. Particularly, the first one was attributed to the effect of mother tongue, Arabic. The second was the lack of sufficient practice of listening aids. The last one was the inadequate pronunciation of the university instructor.

Similarly, Al-Buainain (2007) conducted another research by examining 40 exam scripts of the first writing course to identify the problems Arab students faced in English writing at Qatar University. The researcher has published the common errors Arab students committed in their writing papers. She identified and then classified the committed errors mainly by focusing on some syntactic features such as verbs, relative clauses, articles, fragments, noun modifiers, and prepositions. She finally reached the conclusion that some of the errors are due to the negative interference of L1 habits and some of the errors were caused due to students' lack of sufficient knowledge in English.

In another study conducted by Ali (2007) at University of Mosulon, interlingual errors or interferences from Arabic into English were studied. The researcher addressed the areas of spelling, pronunciation, and some syntactic features, namely, verbs, relative clauses, articles, and prepositions, as the most common errors Arab students committed due to the major effect of their L1.

There is another study conducted by Saigh and Schmitt (2012), concerned Arabic ESL learners' difficulties with L2 vocabulary word form. This study revealed that Arabic learners transferred their L1 processing routines over the L2 in their attempts to process L2 forms. The results of this study showed that students have difficulty with short and long English vowels. Students have difficulty with selecting or recognizing vowels, especially short vowels. According to the collected samples, the author concluded that L1 had a major influence on processing English short and long vowels which affected Arab learners' abilities of spellings of English words.

In another study, Sawalmeh (2013) conducted another examined 32 essays of Saudi students to investigate the errors the students had committed. The results showed that the Arab students committed 10 common errors: verb tense, word, order, singular/plural form, subject-verb agreement, double negative, spelling, capitalization, articles, sentence fragments and prepositions. The researcher studied the types, frequency, and percentage of students' errors. After examining students' errors, it was concluded that most of the students' errors were due to the influence of L1.

\section{SIGNIFICANCE OF ERROR ANALYSIS}

Through analyzing ESL learners' errors and identifying the sources of the highlighted errors, the experience of learning and teaching will appear to be remarkable for both ESL learners and teachers. For some researchers, error analysis is the most effective and operative way to adopt proper system of teaching for students. As Corder (1967) mentioned the significance of errors for three groups including teachers, researchers, and language learners are highly important. Error analysis is an instrument for teachers to observe how far their learners are progressing, while learners' errors can be regarded as evidence for the researchers to study the strategies the learner utilizes to learn the language. As far as the last group is concerned, the learners' errors are committed as a device to acquire the new language. Errors simply occur when learners start to test their hypotheses of the new language. Therefore, errors are regarded as the means used by learners to acquire a new language. Corder asserts that teachers cannot help their students to acquire a language until they recognize the errors and the systems the learners are employing for 
learning a new language. Through the learners' errors, teachers are likely to control and determine their syllabus for teaching and students' learning L2.

The difficulty of the second language learning diminishes when students as main parts of the learning process become aware of their learning systems and also become conscious of the distinction between their L1 and L2. Raising students' awareness of this distinction is vital due to the fact that the structures of the two languages are dissimilar. Therefore, according to Corder (1967), the second language learner has to be aware of the systems of both languages. He needs to investigate the similarities and differences between the two as well as the nature of the language he is learning which will provide him with new and different hypotheses.

In the same vein, Khansir (2012) stated that the significance of the errors is of high value to teachers for whom the identified errors can be considered as helpful devices to recognize the type and nature of the errors students are making. This identification can significantly result in implementing effective-teaching methods. This strategy, based on learners' errors, needs to be accompanied with supportive materials. Through the strategy of identification, observation, and analysis of students' errors, teachers are able to systematize their teaching methods. Conversely, the persistence in repeating such errors can be the consequence of ignoring the students' inaccuracies. When Corder (1967) differentiated the differences between "errors" and "mistakes", he also noted that student's errors are considered as systematic errors which enable teachers to "reconstruct his knowledge of the language to date" (Corder 1967: 167).

Similarly, Jayasundara and Premarathna (2011) accentuated the importance of paying attention to the students' errors. It was pointed out that how ignoring L2 learners' errors can result in continuous repetition of errors which easily leads to the discouragement of the learners. In other words, when errors are ignored, L2 learners become determined to stick to their old language habits and mother-tongue, with this assumption, they use the correct structure in learning L2. Since the underlying objective of teaching is to help students produce a composition with minimum errors, therefore, it is substantial to find out the difficulties students are facing as well as the causes of these errors. Some scholars, like Heydari and Bagheri (2012), are attentive of L2 learners' writings. Their study stresses the significance of the identification and understanding of the committed errors as well as the origins of these errors in the L2 learners' writings. Considering this as a significant point of teaching, L2 instructors will be able to assist their students in the implication of operative strategies in an effective manner. The main logic for the emphasis on L2 learners' writing, as stated in Al-Buainain's article (2007), is because through writing, as a key tool, students are able to display the techniques and systems they utilize to communicate in another language.

There are many reasons causing L2 learners' errors. The main focus of this study is the interference of the native language. The interference of the mother-tongue is more palpable when ESL learners adopt $\mathrm{L} 1$ rules and apply them in the new language in order to communicate their knowledge in L2. As cited in Sanusi's reasecrh paper (1988: 3), Schacher and Celce-Murccia (1977) stated that students' reliance on the L1, or mother-tongue is known as the primary source of students' errors.

\section{METHODOLOGY}

One of the foundation classes at Arab Open University, Oman was randomly chosen to conduct this study. Accordingly, 24 Arab students studying at this university all belonging to one class in bridging language courses were chosen. The students' writings were observed to examine and discuss the structure.

Students were given two topics in different occasions. In the first writing, students were required 
to write one paragraph freely without any limitation to the number of words. They were required to describe their home country, Oman. The reason behind this activity was to observe their structure output (indefinite article + adjective + noun, etc.). Following the same technique, in the second writing, students were asked to write the reasons why learning English as a second language is important. The chief aim of the second writing was to examine students' sentence structures with subordinate conjunction "because". The main reason behind choosing the selected structures was that they were included in the course syllabus focused by English teachers at the foundation level.

A cross check with some native-speaker Arabic instructors have been conducted to analyze such errors and to compare them with how the structure is in Arabic.

\section{FINDINGS}

One column shows the incorrect sentences generated by the students while the opposite column shows how the sentence should have been written in English in addition to the correct form in Arabic which explains why the students' sentences resulted erroneous due to literal translation.

\section{Discussion 1}

Unlike English structure, in Arabic language structure, the noun comes first and then adjective. As students' samples illustrate, the straight transfer of the structure from their mother-tongue into L2 is noticeable (see Table 1).

\section{Discussion 2}

The second point that highlights the first language interference in students' writings is the absence of indefinite article (a/an). Given that Arabic language structure lacks indefinite article in building a phrase with an adjective and a subject, indefinite articles were not used by students in their English output. Students' errors in these examples demonstrate how Arabic structure has been employed in order to form sentences. Obviously, students' first language had a great role in building English sentences. The main causes of wrong structures are "interlingual errors", i.e., the interference of the mother tongue in L2. According to Al-Buainain (2007), Qatar University students had difficulty in distinguishing the difference between definite and indefinite articles, while Omani students' sole problem was the omission of indefinite article (a/an) (see Table 2).

\section{Discussion 3}

By studying sentence (a) in Arabic, it is obvious that (لأن) in Arabic language replaces "because" in English, which is followed by (ي) standing for the subject (I). In Arabic, the subject merges into the subordinate conjunction (لأن). In some sentences in these samples, the structure slightly changes (ل) stands solely for "in order to" which is directly followed by the verb (أتكلم) in which the subject has merged in the verb. Since the subject (انا) is not used separately as it is the case in English structure, it is not an easy task for students to identify and use the subject after the verb. This can be a main reason why students have omitted the usage of the subject "I" in their writings. Students-as it appears to be the case in Arabic structure-believe that the verb "speak" does not need any subject because to them "because speak" implies "because I speak" or "in order to speak" (see Table 3).

According to a study conducted by Al-Buainain (2007), she mentioned three forms of sentence formation in Arabic structure: SVO (Subject Verb Object), VSO (Verb Subject Object), starting with verb. And the last one is equational sentence. Omani students' samples confirm the influence of VSO structure in L2 writing. According to the collected samples, by Omani students, it is obvious that they have difficulty with joining two clauses with "because" which needs to be followed by a subject, by simply 
Table 1. Adjective + Noun Order

\begin{tabular}{|c|c|}
\hline Incorrect & Correct \\
\hline There are many food famous. & 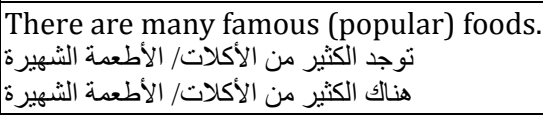 \\
\hline Incorrect & Correct \\
\hline I like weather cold. & $\begin{array}{l}\text { I like cold weather. } \\
\text { أنا أحب الطقس البارد }\end{array}$ \\
\hline Incorrect & Correct \\
\hline I like halwa Omani. & $\begin{array}{l}\text { I like Omani Halwa. } \\
\text { أنا أحب الحوى العُمانية }\end{array}$ \\
\hline Incorrect & Correct \\
\hline The sport famous in Oman is football. & 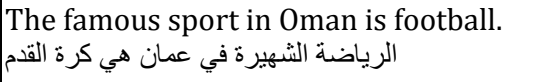 \\
\hline
\end{tabular}

Table 2. Omission of Indefinite Article (a/an Adjective + Noun)

\begin{tabular}{|l|l|}
\hline Incorrect & Correct \\
\hline It is good country. & $\begin{array}{l}\text { It is a good country. } \\
\text { هو بلد }\end{array}$ \\
\hline
\end{tabular}

\begin{tabular}{|l|l|}
\hline Incorrect & Correct \\
\hline It is very delicious food. & $\begin{array}{l}\text { It is a very delicious food. } \\
\text { إنه طعام لذيذ جدأ }\end{array}$ \\
\hline
\end{tabular}

\begin{tabular}{|l|l|}
\hline Incorrect & Correct \\
\hline My country is special country. & $\begin{array}{l}\text { My country is a special country. } \\
\text { بلدي بلد مميز }\end{array}$ \\
\hline
\end{tabular}

\begin{tabular}{|c|c|}
\hline Incorrect & Correct \\
\hline Oman is big city. & $\begin{array}{l}\text { عُمان مدينة كبيرة } \\
\text { Oman is a big country. } \\
\text { عُمان بلد كبير } \\
\text { (correct) }\end{array}$ \\
\hline
\end{tabular}

\begin{tabular}{|l|l|}
\hline Incorrect & Correct \\
\hline My country is beautiful country. & $\begin{array}{l}\text { My country is a beautiful country. } \\
\text { جلدي بلد }\end{array}$ \\
\hline
\end{tabular}

\begin{tabular}{|l|l|}
\hline Incorrect & Correct \\
\hline I am Omani person. & I am an Omani person. \\
& انا شخص عماني \\
\hline
\end{tabular}


Table 3. Subject Omission After "Because"

\begin{tabular}{|l|l|}
\hline Incorrect & Correct \\
\hline Because speak with my family and friends & Because I speak with my family and friends. \\
& لأنتي أتكلم مع عائلتي و أصدقائي (a) \\
& (b) التكلم مع عائلتي و أصدقائي (b) \\
\hline
\end{tabular}

\begin{tabular}{|c|c|}
\hline Incorrect & Correct \\
\hline Because find job & $\begin{array}{l}\text { Because I want to find a job. } \\
\text { لأنني أريد أن أجد وظيفة }\end{array}$ \\
\hline
\end{tabular}

\begin{tabular}{|l|l|}
\hline Incorrect & Correct \\
\hline Because need in the study & Because I need it in my studies. \\
& لأنني أحتاجه في دراساتي \\
\hline
\end{tabular}

\begin{tabular}{|l|l|}
\hline Incorrect & Correct \\
\hline Because is important in my life & $\begin{array}{l}\text { Because it is important in my life. } \\
\text { لأنها مفيدة في حياتي }\end{array}$ \\
\hline
\end{tabular}

\begin{tabular}{|c|c|}
\hline Incorrect & Correct \\
\hline Because to communicate in another country & 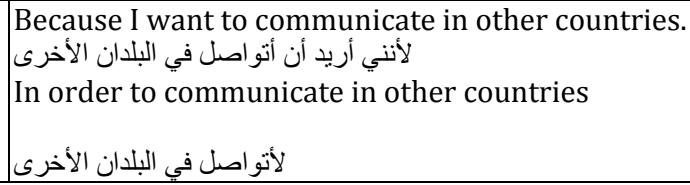 \\
\hline
\end{tabular}

\begin{tabular}{|c|c|}
\hline Incorrect & Correct \\
\hline Because to read. & 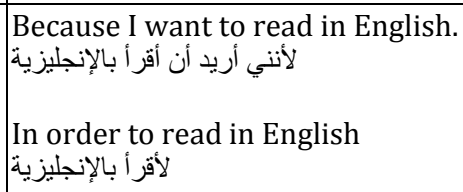 \\
\hline
\end{tabular}

\begin{tabular}{|l|l|}
\hline Incorrect & Correct \\
\hline Because will want to travel & $\begin{array}{l}\text { Because I will travel. } \\
\text { لأنتي سأسافي }\end{array}$ \\
\hline
\end{tabular}

\begin{tabular}{|l|l|}
\hline Incorrect & Correct \\
\hline Because go out Oman & $\begin{array}{l}\text { Because I will travel out of Oman. } \\
\text { لأنني سأسافر خارج عُمان }\end{array}$ \\
\hline
\end{tabular}


sticking to L1 (VSO) habit.

\section{CONCLUSIONS}

Students will never keep repeating the same errors, as their language accuracy is subject to a continuous process of development and progress. Being aware of the errors the language learners commit will assist ESL teachers to adopt and implement effective techniques and systems for language teaching which can simultaneously render students awareness of the differences of the two languages. The results ascertained that the students' most frequent structural errors are mainly due to literal translation from the mother-tongue. An eventual future study will focus on the same students' performance and progress by implementing the same technique.

\section{References}

Abdulkareem, M. N. 2013. “An Investigation Study of Academic Writing Problems Faced by Arab Postgraduate Students at University Technology of Malaysia." Theory and Practice in Language Studies 3(9):1552-1557.

Al-Buainain, H. 2007. "Researching Types and Causes of Errors in Arabic Speakers' Writings.” Pp. 1-37 in Research in ELT Context, edited by S. Midraj, A. Jendli, and Sellami. UAE.

Ali, N. A. 2007. "Some Linguistic Problems Facing Arab Learners of English." Arab Al-Rafidayn 48:1-14.

Al-Khresheh, M. H. 2011. "An Investigation of Interlingual Inference in the Use of 'and' as a Syntactic Coordinating Structure by Jordanian EFL Learner." European Journal of Social Science 18(3):426-433.

Al-Mekhlafi, M. A. A. 2013. "A Study of Question Formation in the English Writing of Omani EFL Learners." Standard Journal of Foundation and Essay 1(4):57-62.

Corder, S. P. 1967. "The Significance of Learners' Error." IRAL 4:161-169.
Heydari, P. and M. S. Bagheri. 2012. "Error Analysis: Sources of L2 Learners' Errors." Theory and Practice in Language Studies 2(8):1583-1589.

Jayasundara, J. M. P. V. K. and C. D. H. N. Premarathna. 2011. "A Linguistics Analysis on Errors Committed in English by Undergraduates." International Journal of Scientific and Research Publications 1(1):1-6.

Khansir, A. A. 2012. "Error Analysis and Second Language Acquisition." Theory and Practice in Language Studies 2(5):1027-1032.

Na'ama, A. 2011. "An Analysis of Errors Made by Yemeni University Students in the English Consonant-Clusters System.” Damascus University Journal 27(3-4):145-161.

Saigh, K. and N. Schmitt. 2012. "Difficulties With Vocabulary Word Form: The Case of Arabic ESL Learners." An International Journal of Educational Technology and Applied Linguistics 40(1):24-36.

Sanusi, I. O. 1988. Semantic Interlingual Errors in the Performance of Yoruba Learners of English as a Second Language: A Case of Negative Transfer. Linguistics and Nigerian Languages, University of Ilorin, Ilorin, Nigeria.

Sawalmeh, M. H. M. 2013. "Error Analysis of Written English Essays: The Case of Students of the Preparatory Year Program in Saudi Arabia." English for Specific Purposes World 14(40):1-17.

Touchie, H. Y. 1986. "Second Language Learning Errors Their Types, Cause, and Treatment." JALT Journal 8.1:75-80.

Yousefi, S., A. Soori, and A. Janfaza. 2014. "Common Preposition Errors Committed by Iranian Students." International Journal of Applied Linguistics \& English Literature 3(3):1-9.

\section{Bio}

Elnaz Valaei Bakhshayesh, MA in English Language and Literature, English Language Lecturer, English Language Department, Arab Open University, Sultanate of Oman; research fields: analyzing and developing ESL students' writings, the effects of technology on learning a new language, error analysis, and supervising students' verbal and written output. 